\title{
LACTIC ACID BACTERIA AND THEIR ROLE IN THE MEAT PROCESSING
} \section{МОЛОЧНОКИСЛЫЕ БАКТЕРИИ И ИХ РОЛЬ В ПЕРЕРАБОТКЕ МЯСА}

\author{
Josef Kameník, Marta Dušková \\ University of Veterinary and Pharmaceutical Sciences, Brno, Czech Republic
}

Ключевые слова: ферментация, порча, консервирующяая упаковка, мясопродукты, термообработка

\begin{abstract}
Аннотация
Молочнокислые бактерии (МКБ) играют в мясной промыциленности как положительную, так и отрицательную роль. Основная польза МКБ в производстве сухих ферментированных колбас заключается в ферментаиии сахаридов, т.е., образовании молочной кислоты и последующем падении $\mathrm{pH}$. Роль МКБ в порче сырого мяса всё ещё неоднозначная. Несколько видов способны доминировать в мясной системе в условиях хранения в вакуумных упаковках и в модифииированной атмосфере и могут выделять молекуль, оказывающие влияние на запах. С другой стороны, они могут проявлять благоприятную антагонистическую активность против нежелательных микроорганизмов. МКБ являются важными возбудителями порчи в варёных мясопродуктах.
\end{abstract}

\section{Введение}

Молочнокислые бактерии (МКБ) - это группа грамположительных бактерий, объединенных определенными морфологическими, метаболическими и физиологическими характеристиками. Они представляют собой неспорообразующие, не являющиеся аэробами, но аэротолерантные, каталазоотрицательные кокки или палочки, которые вырабатывают молочную кислоту как один из основных продуктов ферментации углеводов (Leroi, 2010; von Wright and Axelsson, 2012). Благодаря своей аэротолерантной анаэробной природе, МКБ присутствуют в широком диапазоне естественной окружающей среды, включая желудочно-кишечный тракт человека и животных (Toomey et al., 2010). МКБ традиционно ассоциированы с ферментацией пищевых продуктов и кормов, и обычно считаются благоприятными микроорганизмами. Люди эмпирически использовали МКБ для естественной ферментации молока, мяса, овощей и фруктов в течение тысячелетий, что приводило к новому стабильному продукту. Применение процесса подкисления, обусловленного выработкой молочной кислоты как основного конечного метаболита ферментации углеводов, является основным из наиболее желательных побочных эффектов их роста, ингибируя микроорганизмы, в том числе, наиболее распространенные человеческие патогены (Leroi, 2010).

При переработке мяса МКБ могут играть как положительную, так и отрицательную роль. Положительный эффект связан с ростом МКБ во время ферментации и созревания сухих ферментированных колбас. Отрицательная роль может быть ассоциирована с порчей мяса, выработкой биогенных аминов и распространением генов антибиотикорезистентности (Talon and Leroy, 2011; Toomey et al., 2010).

\section{МКБ в ферментированных мясных продуктах}

Ферментированные пищевые продукты имеют более продолжительный срок хранения по сравнению
Keywords: fermentation, spoilage, preservative packaging, meat products, heat treatment

\section{Abstract}

Lactic acid bacteria (LAB) play in meat processing a positive but also a negative role. The principal advantage of $L A B$ in the production of dry fermented sausages lies in the fermentation of saccharides, i.e. the creation of lactic acid and the subsequent fall in $\mathrm{pH}$. The role of $L A B$ in fresh meat spoilage is still controversial. Several species are able to dominate the meat system in VP and MAP storage conditions and can release odor-impact molecules. On the other hand they can provide favorable antagonistic activity against other undesired microorganisms. LAB are important spoilage agents in cooked meat products.

\section{Introduction}

Lactic acid bacteria constitutes a group of gram-positive bacteria united by certain morphological, metabolic and physiological characteristics. They are nonsporulating, nonrespiring but aerotolerant, catalase negative cocci or rods, which produce lactic acid as one of the main fermentation products of carbohydrates (Leroi, 2010; von Wright and Axelsson, 2012). Due to their aerotolerant anaerobic nature, LAB occupy a wide range of natural environments including gastrointestinal tract of humans and animals (Toomey et al., 2010). LAB have traditionally been associated with food and feed fermentation, and are generally considered beneficial microorganisms. Human has empirically used LAB for natural fermentation ofmilk, meat, vegetables and fruits for thousands of years that led to a new stabilized product. The acidification process due to the lactic acid production as the major end-metabolite of the carbohydrate fermentation is one of the most desirable side effects of their growth, inhibiting micro-organisms including the most common human pathogens (Leroi, 2010).

In the meat processing LAB can play a positive but also negative role. The positive effect is connected with the growth of the $\mathrm{LAB}$ during fermentation and ripening of dry fermented sausages. The negative role can be associated with the meat spoilage, production of biogenic amines and distribution of antimicrobial resistance genes (Talon and Leroy, 2011; Toomey et al., 2010).

\section{$L A B$ in fermented meats}

Fermented foods generally have a longer shelf life than their original raw materials and their spoilage process has a different character. The antimicrobial effects of fermentation are not confined to spoilage organisms alone and can also affect pathogens that might be present (Adams and Mitchell, 2002). In microbiology, the term fermentation can be used to describe either microbial processes that produce useful products or a form of 
с исходным сырьем, и процесс их порчи имеет другой характер. Антимикробные эффекты ферментации не ограничиваются только микроорганизмами, вызывающими порчу, и могут также оказывать влияние на патогены, которые могут присутствовать в продукте (Adams and Mitchell, 2002). В микробиологии термин ферментация может быть использован для описания или микробных процессов, которые приводят к образованию полезных продуктов, или формы роста анаэробных микроорганизмов, использующих внутренние акцепторы электронов и образующих АТФ в основном через фосфорилирование на уровне субстрата (Kim and Gadd, 2008). МКБ играют доминирующую роль в ферментации фарша, приготовленного для производства сухих ферментированных колбас. МКБ, однако, составляют только часть общей микробной популяции в мясе при естественных условиях.

Исходная популяция МКБ в сырье обычно низкая (3-4 $\log \mathrm{KOE} / г)$, но она становиться доминирующей во время этапа ферментации (8 log KОЕ/г) в традиционных колбасах (Talon and Leroy, 2011). После добавления стартовых культур МКБ начинают размножаться от исходной популяции 6,5 $\log \mathrm{KOE} / \Gamma^{-1}$ до 8,0-9,0 $\log \mathrm{KOE} / \Gamma^{-1}$ в течение первых нескольких дней (Kameník et al., 2013; Matagaras et al., 2015). Połka et al. (2015) установили, что популяция МКБ составляла от $<2 \log \mathrm{KOE} / \Gamma^{-1}$ до $4,52 \log \mathrm{KOE} / \Gamma^{-1}$ в образцах колбасы Piacentino (северная Италия) без стартовых культур сразу же после шприцевания в оболочки. Добавление стартовых культур вызывало увеличение МКБ с начала ферментации до уровней между 5,63 и $6,82 \log \mathrm{KОЕ} / \Gamma^{-1}$. После трех недель созревания, популяция МКБ достигала уровней между 8,15 и 8,89 $\log \mathrm{KOE} / \Gamma^{-1}$; в это время не было очевидных различий в количестве МКБ между колбасами, в которых использовались стартовые культуры и колбасами, в которых они не использовались. Во время исследования минисалями, шприцованной в целлюлозные оболочки диаметром 25 мм, Gareis et al. (2010) установили увеличение популяций МКБ (при добавлении стартовых культур) на два логарифма в течение первых трех дней. Количество МКБ не снижалось ниже $8 \log \mathrm{KOE} / \Gamma^{-1}$ ни в какой период в течение эксперимента (42 дня).

Главным преимуществом МКБ при производстве сухих ферментированных колбас является ферментация сахаридов, т.е., образование молочной кислоты и последующее падение рН. Это, однако, не является единственным положительным эффектом этой группы бактерий. Она также играет важную роль в выделении других активных ароматических (вкусовых) веществ и выработке антимикробных соединений. В течение своей жизни МКБ выделяют вещества во внешнюю окружающую среду, многие из которых обладают прямым антибактериальным эффектом. Это могут быть пероксид водорода или органические кислоты. Бактериоцины имеют более сложную структуру (de Souza Barbosa et al., 2015).

\section{Роль МКБ в порче мяса}

Мясо считается одним из наиболее скоропортящихся продуктов. Это обусловлено его химическим составом, который благоприятствует росту микроорга- anaerobic microbial growth using internally supplied electron acceptors and generating ATP mainly through substrate level phosphorylation (Kim and Gadd, 2008). LAB play the predominant role in fermenting the batter made for the preparation of dry fermented sausages. $\mathrm{LAB}$, however, make up just part of the total microbial population in meat under natural conditions.

The initial population of LAB is usually low in the raw material (3 to $4 \log \mathrm{CFU} / \mathrm{g}$ ) but it becomes dominant during the fermentation step ( 8 log CFU/g) in traditional sausages (Talon and Leroy, 2011). Following the addition of starter cultures, LAB can multiply from an initial population of $6.5 \log \mathrm{cfu} \mathrm{g}^{-1}$ to $8.0-9.0 \mathrm{log} \mathrm{cfu} \mathrm{g}^{-1}$ over the first few days (Kameník et al., 2013; Matagaras et al., 2015). Połka et al. (2015) found a LAB population from $<2 \operatorname{log~cfu~g}^{-1}$ to $4.52 \mathrm{log}_{\mathrm{cfu} \mathrm{g}}{ }^{-1}$ in samples of Piacentino sausages (northern Italy) without starter cultures immediately after their filling into casings. The addition of starter cultures caused an increase in LAB from the beginning of fermentation to values of between 5.63 and $6.82 \mathrm{log} \mathrm{cfu} \mathrm{g}^{-1}$. After three weeks of ripening, the $\mathrm{LAB}$ population reached values of between 8.15 and $8.89 \log \mathrm{cfu}$ g- 1 ; at this time there was no evident difference in the number of LAB seen between sausages in which starter cultures were used and sausages in which they were not used. During tests on minisalami filled into cellulose casings of a diameter of $25 \mathrm{~mm}$, Gareis et al. (2010) recorded an increase in the LAB population (with the addition of starter cultures) of two logarithmic orders during the first three days. The number of LAB did not fall beneath $8 \log \mathrm{cfu} \mathrm{g}^{-1}$ at any time during the course of the experiment (42 days).

The principal advantage of LAB in the production of dry fermented sausages lies in the fermentation of saccharides, i.e. the creation of lactic acid and the subsequent fall in $\mathrm{pH}$. This is not, however, the only positive effect of this group of bacteria. It is also important in releasing other active aromatic (taste) substances and producing antimicrobial compounds. During their lifetime, LAB excrete substances into the external environment, many of which have a direct antibacterial effect. These may be hydrogen peroxide or organic acids. Bacteriocins have a more complicated structure (de Souza Barbosa et al., 2015).

\section{The role of $L A B$ in the meat spoilage}

Meat is recognized as one of the most perishable foods. This is due to its chemical composition that favours microbial growth to unacceptable levels contributing significantly to meat deterioration or spoilage (Doulgeraki et al., 2012). It is well established that spoilage of meat is the result of decomposition and formation of metabolites caused by the growth and enzymatic activity of microorganisms (Argyri et al., 2015). Meat spoilage is usually caused by Gram negative bacteria (pseudomonads, Enterobacteriaceae, Shewanella putrefaciens) and several Gram positive (LAB, Brochothrix thermosphacta, clostridia) that dominate under different conditions (Pothakos et al., 2015). A preservative packaging has been widely used to extend the shelf life of fresh meat during distribution and retail sale. High-oxygen modified atmosphere packaging (MAP) has become widespread in recent decades for red meat. Oxygen concentrations of $70-80 \%$ ensure that oxymyoglobin is produced in surface 
низмов до неприемлемых уровней, внося существенный вклад в ухудшение качества или порчу мяса (Doulgeraki et al., 2012). Хорошо известно, что порча мяса является результатом разложения и образования метаболитов, вызванных ростом и ферментативной активностью микроорганизмов (Argyri et al., 2015). Порча мяса обычно вызывается грамотрицательными бактериями (псевдомонады, Enterobacteriaceae, Shewanella putrefaciens) и несколькими грамположительными (МКБ, Brochothrix thermosphacta, клостридии), которые доминируют при различных условиях (Pothakos et al., 2015). Для удлинения продолжительности хранения сырого мяса во время дистрибуции и розничной торговли широко используется консервирующая упаковка. Упаковка красного мяса в модифицированной атмосфере (MAP) с высоким содержанием кислорода стала широко распространенной в последние десятилетия. Концентрации кислорода 70-80\% приводят к образованию оксимиоглобина в поверхностных слоях мяса. Оставшиеся 20-30\% в модифицированной атмосфере приходятся на СО2. Диоксид углерода ингибирует рост бактерий, удлиняя лаг-фазу и время размножения. Концентрация $\mathrm{CO}_{2}$, равная 25\% , близка к максимальному ингибированию аэробной микрофлоры, которая затем снижается до <20\%. Благодаря используемой смеси газов, обычная продолжительность хранения упакованного в модифицированной атмосфере мяса составляет от 10 до 14 дней. Второй тип консервирующей упаковки - это вакуумная упаковка (VP, CVP). Обычная продолжительность хранения вакуум-упакованной говядины и свинины составляет 28 и 21 день, соответственно. Альтернативной и относительно недавний тип розничной упаковки - это вакуумная скин-упаковка (VSP). Это относительно новый метод вакуумной упаковки включает размещение продукта на лотках и обертывание его в пленку под вакуумом при повышенной температуре. Нагревание приводит к размягчению верхней пленки, которая затем плотно покрывает продукт, поэтому и используется термин «скин» («кожа»). Эта процедура способствует более мягкому использованию вакуума. Результатом является снижение потерь сока и более длительная продолжительность хранения по сравнению с традиционной вакуумной упаковкой. Kameník et al. (2014) сравнивали микробиологические свойства упакованных в вакуумную скин-упаковку говядины и свинины с говядиной и свининой, упакованных в традиционную вакуумную упаковку и в упаковку с модифицированной атмосферой (табл. 1). Общее количество жизнеспособных микроорганизмов на 35 день хранения для говядины было между 6,3 и 7,8 $\log _{10} \mathrm{KOE} / \Gamma^{-1}$, без достоверных различий между индивидуальными типами упаковки. В свинине, популяции бактерий на 21 день были между 5 и $6 \log _{10} \mathrm{KOE} / \Gamma^{-1}$. Были установлены сопоставимые уровни в популяциях психротрофных бактерий. Однако различия между индивидуальными типами упаковки отражались в представлении отдельных групп бактерий. Вакуумная упаковка определенно увеличивала развитие МКБ. Количества МКБ, определенные в свинине и говядине, упакованной в модифицированной атмосфере, были значительно ниже, чем те, которые были установлены в свинине, упакованной layers of meat. The remaining $20-30 \%$ in the modified atmosphere is $\mathrm{CO}_{2}$. Carbon dioxide inhibits bacterial growth by extending the lag phase and generation time. A twenty-five percent $\mathrm{CO}_{2}$ concentration is close to the maximum inhibition of aerobic microflora, which then decreases at $<20 \%$. Thanks to the mixture of gases used, the usual shelf life of MAP meat is 10 to 14 days. The second type of preservative packaging is vacuum packing (VP, CVP). The typical shelf life of vacuum-packed beef and pork is 28 and 21 days, respectively. An alternative and a relatively modern type of retail meat packaging is vacuum skin packaging (VSP). This relatively new method of vacuum packaging involves placing the product on a tray and wrapping it in a film under a vacuum at an elevated temperature. The heat causes the softening of the top film which then tightly covers the product, hence the designation of "skin". This procedure allows a gentler use of vacuum. The result is a decrease in purge loss and a longer shelf life in comparison with conventional vacuum packaging. Kameník et al. (2014) compared microbiological properties of vacuum skin packaged beef and pork with beef and pork packaged in conventional vacuum packaging and modified atmosphere packaging (Table 1).

The total viable count on day 35 of storage for beef was between 6.3 and $7.8 \log _{10}$ cfu.g g $^{-1}$ with no significant differences between individual types of packaging. In pork, the bacterial population on day 21 was between 5 and $6 \log _{10}$ cfu.g ${ }^{-1}$. Comparable values were found in the population of psychrotrophic bacteria. Differences between individual types of packaging were, however, reflected in the representation of selected bacterial groups. Vacuum packaging clearly enhanced the development of LAB. LAB counts determined in pork and beef packed in a modified atmosphere were significantly lower than those found in pork in CVP and VSP ( $\mathrm{P}=0.044$ and 0.018 , respectively) and beef in CVP and VSP $(\mathrm{P}=0.006$ and 0.003 , respectively). From day 14 of storage onwards, the LAB population in meat samples in CVP and VSP was $2 \log _{10}$ larger than that in MAP meat. The differences remained unchanged throughout the experiment.

Currently, the role of LAB in fresh meat spoilage is still controversial. On one side, several species are able to dominate the meat system in VP and MAP storage conditions and can release odor-impact molecules, which may alter the sensory profile of raw or cooked meat, albeit this is not the case in all documented reports. The spoilage character of some LAB taxa is ambiguous and probably correlated with specific spoilage-associated capacities of individual strains that cannot be attributed collectively to the respective species. Moreover, for the LAB with negligible role in sensory spoilage, a bioprotective function in meat can be hypothesized as they can provide favorable antagonistic activity against other undesired microorganisms (Pothakos et al., 2015).

\section{LAB as a spoilage agent of meat products}

The ability of bacteria to adapt to the conditions of the external environment is a key factor in determining whether they survive and continue to grow. Psychrotrophic lactic acid bacteria (LAB) are well adapted to the environment of meat products, which are characterised by microaerophilic conditions along with a lower 
в вакуумную упаковку и вакуумную скин-упаковку ( $\mathrm{P}=0,044$ и 0,018, соответственно), и говядине, упакованной в вакуумную упаковку и вакуумную скин-упаковку ( $\mathrm{P}=0,006$ и 0,003, соответственно).

Начиная с 14 дня хранения популяции МКБ в образцах мяса в вакуумной упаковке и вакуумной скин-упаковке были на $2 \log _{10}$ больше по сравнению с мясом, упакованным в модифицированной атмосфере. Различия оставались неизменными на протяжении всего эксперимента.

В настоящее время роль МКБ в порче свежего мяса все еще противоречивая. С одной стороны, несколько видов способны доминировать в мясной системе в условиях хранения в вакуумной упаковке или вакуумной скин-упаковке и могут выделять оказывающие влияние на запах молекулы, что может изменять сенсорный профиль сырого или термообработанного $a_{w}$ value, and in which sodium chloride and nitrite are present (Samelis et al., 2000). Certain species of the genus Lactobacillus, such as L. sakei and L. curvatus, comprise the dominant microflora in dry fermented sausages (Bonomo et al., 2008; Cocolin et al., 2009).

On the other hand, there is also a large group of cooked meat products in which the presence of microorganisms and their metabolic activity is undesirable, as they induce spoilage and therefore reduce the shelf life of the given meat products. Psychrotrophic lactic acid bacteria have a crucial part to play in these negative effects (Slongo et al., 2009; Audenaert et al., 2010). Their presence is often connected with secondary contamination during packing or slicing, as they are not capable of surviving the heating involved in the cooking process (Franz, von Holy, 1996). Thermal resistant species also exist, however, which are not destroyed by higher temperatures (generally $70{ }^{\circ} \mathrm{C}$ ),

Table 1. Microbiological analysis of packaged beef and pork meat samples

(MAP: modified atmosphere, CVP: vacuum, VSP: skin vacuum) during storage (mean \pm s.d., log cfu.g ${ }^{-1}$; Kameník et al., 2014)

Таблица 1. Микробиологический анализ образцов упакованных говядины и свинины

(MAP: модифицированная атмосфера, CVP: вакуумная упаковка, VSP: вакуумная скин-упаковка) во время хранения (средние значения \pm стандартные отклонения, $\log \mathrm{KOE} / \Gamma^{-1}$; Kameník et al., 2014)

\begin{tabular}{|c|c|c|c|c|c|c|c|}
\hline & \multirow{2}{*}{$\begin{array}{l}\text { Day of sampling I } \\
\text { Дни отбора проб }\end{array}$} & \multicolumn{3}{|c|}{ Beef I Говядина } & \multicolumn{3}{|c|}{ Pork I Свинина } \\
\hline & & MAP & CVP & VSP & MAP & CVP & VSP \\
\hline \multirow{5}{*}{ TVC } & $\mathbf{0}$ & \multicolumn{3}{|c|}{$1.37 \pm 0.44$} & \multicolumn{3}{|c|}{$2.55 \pm 0.63$} \\
\hline & 7 & $3.04 \pm 0.72$ & $3.45 \pm 0.15$ & $2.75 \pm 0.31$ & $2.60 \pm 0.29$ & $3.31 \pm 0.55$ & $2.12 \pm 0.46$ \\
\hline & 14 & $3.70 \pm 0.45$ & $4.28 \pm 0.60$ & $3.48 \pm 0.97$ & $4.92 \pm 1.04$ & $4.12 \pm 0.29$ & $4.24 \pm 0.74$ \\
\hline & 21 & $6.66 \pm 0.05$ & $6.94 \pm 0.89$ & $7.15 \pm 0.49$ & $6.37 \pm 0.99$ & $4.87 \pm 0.52$ & $5.03 \pm 0.36$ \\
\hline & 35 & $6.81 \pm 0.51$ & $6.27 \pm 0.68$ & $7.82 \pm 1.71$ & - & - & 一 \\
\hline \multirow{5}{*}{ LAB } & $\mathbf{0}$ & \multicolumn{3}{|c|}{$0.00 \pm 0.00$} & \multicolumn{3}{|c|}{$0.17 \pm 0.32$} \\
\hline & 7 & $0.00 \pm 0.00$ & $0.41 \pm 0.65$ & $0.05 \pm 0.12$ & $0.00 \pm 0.00$ & $0.44 \pm 0.49$ & $0.37 \pm 0.36$ \\
\hline & 14 & $0.34 \pm 0.68$ & $2.50 \pm 0.65$ & $2.51 \pm 0.49$ & $0.10 \pm 0.16$ & $2.10 \pm 0.54$ & $2.37 \pm 0.53$ \\
\hline & 21 & $2.28 \pm 0.98$ & $4.30 \pm 0.88$ & $5.01 \pm 0.92$ & $2.24 \pm 0.84$ & $4.31 \pm 1.04$ & $4.77 \pm 0.76$ \\
\hline & 35 & $1.97 \pm 0.82$ & $4.94 \pm 0.68$ & $5.14 \pm 0.75$ & - & - & - \\
\hline \multirow{5}{*}{ PSY } & $\mathbf{0}$ & \multicolumn{3}{|c|}{$1.33 \pm 0.58$} & \multicolumn{3}{|c|}{$1.79 \pm 0.82$} \\
\hline & 7 & $3.26 \pm 0.94$ & $3.62 \pm 0.18$ & $2.61 \pm 0.97$ & $3.20 \pm 0.36$ & $3.57 \pm 0.59$ & $2.33 \pm 0.40$ \\
\hline & 14 & $3.81 \pm 0.39$ & $3.24 \pm 0.77$ & $1.60 \pm 0.55$ & $2.35 \pm 0.87$ & $2.31 \pm 0.93$ & $1.80 \pm 0.45$ \\
\hline & 21 & $6.22 \pm 0.40$ & $6.02 \pm 0.56$ & $5.70 \pm 0.42$ & $6.17 \pm 1.02$ & $5.53 \pm 0.63$ & $5.46 \pm 0.60$ \\
\hline & 35 & $7.10 \pm 0.51$ & $7.16 \pm 0.22$ & $7.11 \pm 0.27$ & - & - & - \\
\hline \multirow{5}{*}{ PSE } & 0 & \multicolumn{3}{|c|}{$0.33 \pm 0.58$} & \multicolumn{3}{|c|}{$0.40 \pm 0.55$} \\
\hline & 7 & $2.02 \pm 0.23$ & $0.63 \pm 0.88$ & $0.55 \pm 0.76$ & $0.94 \pm 0.99$ & $0.68 \pm 0.65$ & $0.39 \pm 0.54$ \\
\hline & 14 & $2.09 \pm 0.37$ & $0.74 \pm 1.02$ & $0.00 \pm 0.00$ & $2.33 \pm 0.17$ & $2.13 \pm 0.27$ & $1.69 \pm 0.71$ \\
\hline & 21 & $2.04 \pm 0.47$ & $1.46 \pm 0.41$ & $0.00 \pm 0.00$ & $2.31 \pm 0.20$ & $2.12 \pm 0.35$ & $1.96 \pm 0.24$ \\
\hline & 35 & $5.01 \pm 0.97$ & $1.85 \pm 0.36$ & $0.54 \pm 0.89$ & - & - & - \\
\hline \multirow{5}{*}{ BRO } & 0 & \multicolumn{3}{|c|}{$0.00 \pm 0.00$} & \multicolumn{3}{|c|}{$0.00 \pm 0.00$} \\
\hline & 7 & $0.00 \pm 0.00$ & $0.00 \pm 0.00$ & $0.00 \pm 0.00$ & $0.00 \pm 0.00$ & $0.00 \pm 0.00$ & $0.00 \pm 0.00$ \\
\hline & 14 & $0.96 \pm 0.60$ & $0.00 \pm 0.00$ & $0.64 \pm 0.63$ & $0.72 \pm 0.69$ & $0.70 \pm 0.71$ & $0.26 \pm 0.36$ \\
\hline & 21 & $1.81 \pm 0.19$ & $1.13 \pm 0.18$ & $0.42 \pm 0.58$ & $2.15 \pm 0.19$ & $1.50 \pm 0.16$ & $0.13 \pm 0.29$ \\
\hline & 35 & $2.53 \pm 0.73$ & $1.14 \pm 0.66$ & $0.00 \pm 0.00$ & - & - & - \\
\hline \multirow{5}{*}{ COL } & 0 & \multicolumn{3}{|c|}{$0.00 \pm 0.00$} & \multicolumn{3}{|c|}{$0.20 \pm 0.45$} \\
\hline & 7 & $0.00 \pm 0.00$ & $0.00 \pm 0.00$ & $0.00 \pm 0.00$ & $0.00 \pm 0.00$ & $1.35 \pm 0.81$ & $0.80 \pm 0.72$ \\
\hline & 14 & $0.00 \pm 0.00$ & $1.34 \pm 0.98$ & $0.37 \pm 0.51$ & $0.09 \pm 0.19$ & $2.18 \pm 0.36$ & $2.60 \pm 0.28$ \\
\hline & 21 & $0.00 \pm 0.00$ & $1.11 \pm 0.94$ & $1.13 \pm 1.05$ & $0.11 \pm 0.25$ & $3.37 \pm 0.62$ & $3.86 \pm 0.34$ \\
\hline & 35 & $0.00 \pm 0.00$ & $0.99 \pm 1.62$ & $0.67 \pm 0.93$ & - & - & - \\
\hline
\end{tabular}

(TVC = total viable count; $\mathrm{LAB}=$ lactic acid bacteria; PSY = psychrotrophic bacteria; $\mathrm{PSE}=$ Pseudomonas spp.;

$\mathrm{BRO}=$ Brochothrix thermosphacta; $\mathrm{COL}=$ coliform bacteria)

(TVC = общее количество жизнеспособных микроорганизмов; LAB = молочнокислые бактерии; PSY = психротрофные бактерии;

PSE = Pseudomonas spp.; BRO = Brochothrixthermosphacta; COL = колиформные бактерии) 
мяса, хотя это не всегда происходило во всех документированных сообщениях. Характер порчи у некоторых таксонов молочнокислых бактерий неоднозначен и вероятно коррелирует со специфическими ассоциированными с порчей способностями отдельных штаммов, которые не могут быть коллективно приписаны соответствующим видам. Кроме того, для МКБ с незначительной ролью в сенсорной порче, можно предположить биозащитную функцию в мясе, так как они могут предоставить благоприятную антагонистическую активность против других нежелательных микроорганизмов (Pothakos et al., 2015).

\section{МКБ как возбудители порчи мясопродуктов}

Способность бактерий адаптироваться к условиям внешней среды является ключевым фактором в определении того, будут ли они выживать и продолжать расти. Психротрофные молочнокислые бактерии (МКБ) хорошо адаптированы к среде мясных продуктов, которая характеризуется микроаэрофильными условиями наряду с более низким уровнем $\mathrm{a}_{\mathrm{w}}$, и в которых присутствуют хлорид и нитрит натрия (Samelis et al., 2000). Определенные виды рода Lactobacillus, такие как L. sakei и L. curvatus, представляют собой доминирующую микрофлору в сухих ферментированных колбасах (Bonomo et al., 2008; Cocolin et al., 2009).

C другой стороны, также существует большая группа термообработанных мясопродуктов, в которых присутствие микроорганизмов и их метаболическая активность нежелательны, так как они вызывают порчу, и таким образом снижают продолжительность хранения данных мясопродуктов. Психротрофные молочнокислые бактерии играют критическую роль в этих негативных эффектах (Slongo et al., 2009; Audenaert et al., 2010). Их присутствие часто связано с вторичной контаминацией во время упаковки и нарезки, так как они не способны выживать в процессе термообработки (Franz, von Holy, 1996). Однако также существуют термоустойчивые виды, которые не разрушаются более высокими температурами (обычно $70^{\circ} \mathrm{C}$ ), и которые способны к дальнейшему росту при пригодных условиях.

Dušková et al. (2016) провела микробиологический анализ отдельных технологических операций во время промышленного производства вареных окороков с акцентом на МКБ. Образцы отбирали в течение всего цикла производства вареных окороков в мае-июне (эксперимент 1) и ноябре-декабре (эксперимент 2). Всего было отобрано и затем исследовано 215 образцов. Различие в присутствии МКБ в мясе до термообработки происходило от исходного уровня контаминации сырья. Во время термической обработки (температура в центре $70{ }^{\circ} \mathrm{C} / 10$ мин.) происходило снижение количества МКБ от 4,0 - 5,0 $\log \mathrm{KOE} / \Gamma^{-1}$ мяса до практически нулевого уровня. Популяции МКБ увеличивались во время хранения готовых продуктов. Уровень 7,0 $\log \mathrm{KOE} / \Gamma^{-1}$ был достигнут в ломтиках окорока, упакованного в модифицированной атмосфере, после трех (эксперимент 1) или двух (эксперимент 2) недель хранения, соответственно. В образцах вареного окорока после термообработки более часто and which are capable of further growth under suitable conditions.

Dušková et al. (2016) performed microbiological analysis of individual technological operations during the industrial production of cooked hams, focusing on LAB. Samples were taken during the course of the entire cooked ham production cycle in May-June (Experiment I) and November-December (Experiment II). A total of 215 samples were taken and subsequently tested. The difference in the occurrence of $\mathrm{LAB}$ in meat before thermal processing resulted from the initial level of contamination of the raw material. A reduction to the number of LAB from 4.0-5.0 log cfu.g ${ }^{-1}$ of meat to a value of practically zero occurred during the thermal processing (core temperature of $70{ }^{\circ} \mathrm{C} / 10 \mathrm{~min}$ ). The LAB population increased during storage of the finished products. A level of $7.0 \mathrm{log} \mathrm{cfu}^{-1} \mathrm{~g}^{-1}$ was reached in slices of ham in the modified atmosphere after three (Experiment I) or two (Experiment II) weeks of storage, respectively. LAB of the genera Leuconostoc (Leuc. carnosum, Leuc. mesenteroides and Leuc. gelidum) occurred most frequently in samples of cooked ham after thermal processing. These species were also isolated from the production environment. Lactobacillus sakei, Lbc. curvatus and Weissella viridescens were other species of LAB that were isolated from samples after thermal processing (Dušková et al., 2016). The thermal resistance of Weissella viridescens was studied under laboratory conditions $\left(0.9 \% \mathrm{NaCl} ; 50,60\right.$ or $70{ }^{\circ} \mathrm{C} / 5,10$ or $15 \mathrm{~min}$.) and in dry cooked meat products (Kameník et al., 2015). Nine batches of hot smoked dry sausage were prepared differing in terms of the size of the inoculum of $W$. viridescens ( $3 \log \mathrm{cfu}^{\mathrm{g}} \mathrm{g}^{-1}$ of sausage batter, $\left.4 \log \mathrm{cfu} . \mathrm{g}^{-1}\right)$ and the addition of dextrose $(0,0.1,0.2,0.3$ and $0.4 \%) . W$. viridescens was detected in samples with a lower concentration of inoculum only after 2 weeks of ripening. But in batches with a higher concentration of inoculum $W$. viridescens was detected immediately after cooking and the number of cfu exceeded 7 log. $\mathrm{g}^{-1}$ during ripening. The addition of dextrose did not influence the growth of Weissella. Survival of the species W. viridescens in hot smoked dry sausages was also demonstrated under the conditions of industrial production.

Dušková et al. (2015) determined the potential spoilage agent in hot smoked dry sausages. A total of 87 Vysočina sausages obtained from eight producers in the Czech Republic were analysed. The number of LAB ranged from 2.00 to $7.88 \log \mathrm{CFU} / \mathrm{g}$. Weissella viridescens was found in 30 of the 42 samples positive for LAB (71.4\%), in 23 cases $(53.5 \%)$ as a monoculture of LAB. An analysis of the factory environment and raw materials (84 swab samples) for the presence of $\mathrm{LAB}$ was conducted in relation to three producers. The species $W$. viridescens was found in just $2.4 \%$ of all swabs. As total of four samples designated for reworking contained LAB, with three samples being positive for the presence of $W$. viridescens, authors suggested that the reworking process leads to subsequent growth of thermoresistant strains causing spoilage of the sausages (Dušková et al., 2015. 
встречались МКБ рода Leuconostoc (Leuc. carnosum, Leuc. Mesenteroides u Leuc. gelidum). Эти виды также выделяли из производственной среды. Другими видами МКБ, которые выделяли из образцов после термообработки, были Lactobacillus sakei, Lbc. curvatus и Weissella viridescens (Dušková et al., 2016). Изучали термоустойчивость Weissella viridescens в лабораторных условиях $\left(0,9 \% \mathrm{NaCl} ; 50,60\right.$ или $70{ }^{\circ} \mathrm{C} / 5,10$ или 15 мин.) или в сухих вареных мясопродуктах (Kameník et al., 2015). Было изготовлено 9 партий сухой колбасы горячего копчения, которые различались по объему инокулята $W$. viridescens $\left(3 \log \mathrm{KOE} / \mathrm{r}^{-1}\right.$ колбасного фарша, $\left.4 \log \mathrm{KOE} / \Gamma^{-1}\right)$ и добавлению декстрозы $(0 ; 0,1 ; 0,2 ; 0,3$ и $0,4 \%)$. W. viridescens был определен в образцах с более низкой концентрацией инокулята только после 2 недель созревания. Но в фарше с более высокой концентрацией инокулята $W$. viridescens был определен сразу же после термообработки, и количество КОЕ превышало $7 \log \mathrm{KOE} / \mathrm{\Gamma}^{-1}$ во время созревания. Добавление декстрозы не оказывало влияния на рост Weissella. Выживание вида $W$. viridescens в сухой колбасе горячего копчения также было продемонстрировано в условиях промышленного производства.

Dušková et al. (2015) определяли потенциал порчи в сухих колбасах горячего копчения. Всего было анализировано 87 колбас Vysočina, полученных от восьми производителей в Чешской Республике. Количество МКБ было в диапазоне 2,00 до 7,88 $\log \mathrm{KOE} /$ г. Weissella viridescens был обнаружен в 30 из 42 образцов, положительных на МКБ (71,4\%), в 23 случаях (53,5\%) как монокультура МКБ. У трех производителей был проведен анализ окружающей среды предприятия и сырья (84 образцов смывов) на присутствие МКБ. Вид $W$. viridescens был обнаружен только в 2,4\% всех смывов. Всего 4 образца, предназначенных для повторной обработки, содержали МКБ, при этом три образца были положительными на присутствие $W$. viridescens; авторы полагают, что процесс повторной обработки приводит к последующему росту термоустойчивых штаммов, вызывающих порчу колбас (Dušková et al., 2015). 


\section{БИБЛИОГРАФИЧЕСКИЙ СПИСОК | REFЕRЕNСЕS}

1. Adams, M. and Mitchell, R. (2002): Fermentation and pathogen control: a risk assessment approach. International Journal of Food Microbiology, 79, 75 - 83.

2. Argyri, A.A., Mallouchos, A., Panagou, E. Z., Nychas, G.-J. E. (2015): The dynamics of the HS/SPME-GC/MS as a tool to assess the spoilage of minced beef stored under different packaging and temperature conditions. International Journal of Food Microbiology, 193, 51-58.

3. Audenaert, K., D`Haene, K., Messens, K., Ruyssen, T., Vandamme, P. \& Huys, G. (2010): Diversity of lactic acid bacteria from modified atmosphere packaged sliced cooked meat products at sell-by date assessed by PCR-denaturing gradient gel electrophoresis. Food Microbiology, 27, 12 - 18.

4. Bonomo, M.G., Ricciardi, A., Zotta, T., Parente, E. \& Salzano, G. (2008). Molecular and technological characterization of lactic acid bacteria from traditional fermented sausages of Brasilicata region (Southern Italy). Meat Science, 80, 1238 - 1248.

5. Cocolin, L., Dolci, P., Rantsiou, K., Urso, R., Cantoni, C. \& Comi, G. (2009). Lactic acid bacteria ecology of three traditional fermented sausages produced in the Notrh of Italy as determined by molecular methods. Meat Science, 82, 125 - 132.

6. De Souza Barbosa, M., Todorov, S. D., Ivanova, I., Chobert, J. M., Haertlé, T., de Melo Franco, B.D.G. (2015): Improving safety of salami by application of bacteriocins produced by an autochthonous Lactobacillus curvatus isolate. Food Microbiology, $46,254-262$.

7. Doulgeraki, A.I., Ercolini, D., Villani, F., Nychas, G.-J. E. (2012): Spoilage microbiota associated to the storage of raw meat in different conditions. International Journal of Food Microbiology, 157, 130-141.

8. Dušková, M., Kameník, J. Šedo, O., Zdráhal, Z., Saláková, A., Karpíšková, R., Lačanin, I. (2015): Survival and growth of lactic acid bacteria in hot smoked dry sausages (non-fermented salami) with and without sensory deviations. Food Control, 50, 804-808.

9. Dušková, M., Kameník, J., Lačanin, I., Šedo, O., Zdráhal, Z. (2016): Lactic acid bacteria in cooked hams e Sources of contamination and chances of survival in the product. Food Control, 61, 1-5.

10. Franz, C.M.A.P., Von Holy, A. (1996). Thermotolerance of meat spoilage lactic acid bacteria and their inactivation in vacuum-packaged vinna sausages. International Journal of Food Microbiology, 29, 59-73.

11. Gareis, M., Kabisch, J., R. Pichner, R., Hechelmann, H.( 2010): Vorkommen von Lebensmittelinfektionserregern in Minisalamis (Occurence of food borne pathogens in minisalamis). Fleischwirtschaft 90, 4, $179-183$.

12. Kameník, J., Steinhauserová, P., Saláková, A., Pavlík, Z., Bořilová, G., Steinhauser, L., Ruprich, J. (2013): Influence of Various Pork Fat Types on the Ripening and Characteristics of Dry Fermented Sausage. Czech Journal of Food Sciences, 31, 419-431.

13. Kameník, J., Saláková, A., Pavlík, Z., Bořilová, G., Hulánková, R., Steinhauserová, l. (2014): Vacuum skin packaging and its effect on selected properties of beef and pork meat. European Food Research and Technology, 239, 395-402.

14. Kameník, J., Dušková, M., Sedo, O., Saláková, A., Pavlík, Z., Zdráhal, Z., Karpíšková, R. (2015): Lactic acid bacteria in hot smoked dry sausage (non-fermented salami): Thermal resistance of Weissella viridescens strains isolated from hot smoked dry sausages. LWT - Food Science and Technology, 61, 492-495.

15. Kim, B. H., Gadd, G. M. (2008): Bacterial Physiology and Metabolism. Cambridge university press. New York. 529 pp.

16. Leroi, F. (2010): Occurrence and role of lactic acid bacteria in seafood products. Food Microbiology, 27, 698-709.

17. Mataragas, M., Rovetto, F., Bellio, A., Alessandria, V., Rantsiou, K., Decastelli, L. (2015): Differential gene expression profiling of Listeria monocytogenes in Cacciatore and Felino salami to reveal Potential stress resistence biomarkers. Food Microbiology, 46, 408-417.

18. Połka, J., Rebecchi, A., Pisacane, V., Morelli, L., Puglisi, E. (2015): Bacterial diversity in typical Italian salami at different ripening stages as revealed by high-throughput sequencing of 16S rRNA amplicons. Food Microbiology, 46, 342 - 356.

19. Pothakos, V., Devlieghere, F., Villani, F., Björkroth, J., Ercolini, D. (2015): Lactic acid bacteria and their controversial role in Fresh meat spoilage. Meat Science, 109, 66-74.

20. Samelis, J., Kakouri, A. \& Rementzis, J. (2000). Selective effect of the product type and the packaging conditions on the species of lactic acid bacteria dominating the spoilage microbial association of cooked meats at $4{ }^{\circ} \mathrm{C}$. Food Microbiology, 17, $329-340$.

21.Slongo, A.P., Rosenthal, A., Camargo, L.M. Q., Deliza, R., Mathias, S. P., Falcão de Aragão, G.M. (2009): Modeling the growth of lactic acid bacteria in sliced ham processed by high hydrostatic pressure. LWT - Food Science and Technology, 42, 303 - 306

22. Talon, R., Leroy, S. (2011): Diversity and safety hazards of bacteria involved in meat fermentation. Meat Science, 89, $303-309$.

23. Toomey, N., Bolton, D., Fanning, S. (2010): Characterisation and transferability of antibiotic resistence genes from lactic acid bacteria isolated from Irish pork and beef abattoirs. Research in Microbiology, 161, 127-135.

24. Von Wright, A., Axelsson, L. (2012): Lactic Acid Bacteria: An Introduction. In: (Lahtinen, S., Ouwehand, A.C., Salminen, S., von Wright, A.: Lactic acid bacteria. Microbiological and functional aspects. 4th edition, CRC Press, Boca Raton, 779 pp.

\section{СВЕДЕНИЯ ОБ АВТОРАХ}

Принадлежность к организации

Джозеф Каменик, кандидат ветеринарных наук, научный сотрудник кафедры гастрономии, Факультет ветеринарной гигиены и экологии, Университет ветеринарных и фармацевтических наук Брно, Palackého tř. 1946/1; 61242 Брно, Чешская Республика. Тел.: 00420 541562600; e-mail: kamenikj@vfu.cz

Марта Дучкова, Ph.D., кафедра гигиены и технологии, Факультет ветеринарной гигиены и экологии, Университет ветеринарных и фармацевтических наук Брно, Palackého tř. 1946/1; 61242 Брно, Чешская Республика. Тел.: 00420 541562720; e-mail: duskovam@vfu.cz

\section{Критерии авторства}

Ответственность за работу и предоставленные сведения несут все авторы. Все авторы в равной степени участвовали в этой работе.

Авторы в равных долях имеют отношение к написанию рукописи и одинаково несут ответственность за плагиат

Джозеф Каменик корректировал рукопись до подачи в редакцию

$$
\text { Конфликт интересов }
$$

Авторы заявляют об отсутствии конфликта интересов

Поступила 15.12.2015

\section{INFORMATION ABOUT AUTHORS}

\section{Affiliation}

Josef Kameník, candidate of veterinary sciences, Department of Gastronomy; Faculty of Veterinary Hygiene and Ecology, University of Veterinary and Pharmaceutical Sciences Brno, Palackého tř. 1946/1; 61242 Brno, Czech Republic. Ph.: 00420 541562600; e-mail: kamenikj@vfu.cz

Marta Dušková, Ph.D., Department of Milch Hygiene and Technology; Faculty of Veterinary Hygiene and Ecology, University of Veterinary and Pharmaceutical Sciences Brno, Palackého tř. 1946/1; 61242 Brno, Czech Republic. Ph.: 00420 541562720; e-mail: duskovam@vfu.cz

\section{Contribution}

All authors are responsible for the work and given information. All authors were equally involved in this work.

Authors equally relevant to the writing of the manuscript, and equally responsible for plagiarism

Josef Kameník adjusted the manuscript prior to submission to the Editor Conflict of interest

The authors declare no conflict of interest

Received 15.12.2015 